\title{
Inflation targeting, employment creation and economic development: assessing the impacts and policy alternatives
}

\section{Gerald Epstein \& Erinc Yeldan}

To cite this article: Gerald Epstein \& Erinc Yeldan (2008) Inflation targeting, employment creation and economic development: assessing the impacts and policy alternatives, International Review of Applied Economics, 22:2, 131-144, DOI: 10.1080/02692170701880601

To link to this article: https://doi.org/10.1080/02692170701880601

巴fublished online: 18 Mar 2008.

Submit your article to this journal $\sqsubset$

Џلll Article views: 485

Citing articles: 21 View citing articles 5 


\title{
Inflation targeting, employment creation and economic development: assessing the impacts and policy alternatives
}

\author{
Gerald Epstein $^{\mathrm{a}}$ and Erinc Yeldan ${ }^{\mathrm{b}}$ \\ ${ }^{a}$ Political Economy Research Institute and Economics Department, University of Massachusetts, \\ Amherst, MA, USA; ${ }^{b}$ Bilkent University, Ankara, Turkey
}

\begin{abstract}
Inflation targeting (IT) has recently become the dominant monetary policy prescription for both developing and industrialized countries alike. Emerging market governments, in particular, are increasingly pressured to follow IT as part of their International Monetary Fund (IMF)-led stabilization packages and the routine rating procedures of the international finance institutions. However, the common expectation of IT promoters that price stability would ultimately lead to higher employment and sustained growth has failed to materialize. Generally, the current growth patterns of the world economy are too concentrated and uneven to generate sufficient capital investment and reduce unemployment. To contribute to the task of designing a more socially desirable macroeconomic policy environment, we offer concrete country case studies that devise viable alternatives to inflation targeting central bank policies in order to promote employment, sustained growth and improved income distribution.
\end{abstract}

Keywords: inflation targeting; central banks

JEL classification: E31, E58

\section{Introduction}

Inflation targeting (IT) is the new orthodoxy of mainstream macroeconomic thought. The approach has now been adopted by 24 central banks (CBs), and many more, including those in developing countries, are expressing serious interest in following suit. Initially adopted by New Zealand in 1990, the norms surrounding the IT regime have been so powerful that the central banks of both the industrialized and the developing economies alike have declared that maintaining price stability at the lowest possible rate of inflation is their only mandate. It has been generally believed that price stability is a pre-condition for sustained growth and employment, and that 'high' inflation, often defined as more that 5 or $6 \%$ per year, is damaging to the economy in the long run.

In broad terms, the IT policy framework involves 'the public announcement of inflation targets, coupled with a credible and accountable commitment on the part of government policy authorities to the achievement of these targets' (Setterfield 2006: 653). In addition, inflation targeting is usually associated with appropriate changes in the central bank law that enhances the independence of the institution. In practice, while few central banks reach the 'ideal' of being 'fully fledged' inflation targeters, many others still focus on fighting inflation to the virtual exclusion of other goals.

Ironically, employment creation has dropped off the direct agenda of most central banks just as the problems of global unemployment, underemployment and poverty are taking center stage as critical world issues (Heintz 2006). The International Labor Office (ILO) estimates that in 2003,

Corresponding author. Email: gepstein@econs.umass.edu 
approximately 186 million people were jobless, the highest level ever recorded (ILO 2004). The employment to population ratio - a measure of unemployment - has fallen in the last decade, from 63.3 to $62.5 \%$ (ILO 2004). As the quantity of jobs relative to need has fallen, there is also a significant global problem with respect to the quality of jobs. The ILO estimates that $22 \%$ of the developing world's workers earn less than US\$1 a day and 1.4 billion (or 57\% of the developing world's workers) earn less than US\$2 a day. Moreover, China's and India's opening up to the global markets and the collapse of the Soviet system together have added 1.5 billion new workers to the world's economically active population (Freeman 2004; Akyuz 2006). This means almost a doubling of the global labor force and a reduction of the global capital-labor ratio by half. Under these conditions, a large number of developing countries have suffered de-industrialization, serious informalization, and consequent worsening of the position of wage-labor, resulting in a deterioration of income distribution and increased poverty.

The key problem is that ongoing financial globalization appears primarily to redistribute limited jobs across countries, rather than to accelerate capital accumulation and job creation across the globe (Akyuz 2006; Epstein 2005; Adelman and Yeldan 2000). Current growth in the global economy is highly uneven and geographically too concentrated to generate sufficient jobs world-wide and, moreover, is associated with too little fixed capital formation. Under these conditions, price stability, on its own, will not suffice to maintain true macroeconomic stability, because, it will not secure financial stability and employment growth. In the words of Akyuz (2006: 46), '... the source of macroeconomic instability now is not instability in product markets but asset markets, and the main challenge for policy makers is not inflation, but unemployment and financial instability' (emphasis added). The sub-prime financial problems originating in the USA that are now spreading difficulties to many parts of the globe, is only the latest in a series of episodes graphically illustrating the dangers of ignoring financial instability.

While it might seem obvious that stabilization focused central bank policy represents the only proper role for central banks, in fact, looking at history casts serious doubt on this claim. Far from being the historical norm, in many of the successful currently developed countries, as well as in many developing countries in the post-Second World War period, pursuing development objectives was seen as a crucial part of most central banks' tasks (Epstein 2007). Now, by contrast, development has dropped off the policy agenda of central banks in most developing countries.

The theme of this special issue and this introductory paper is that the modern central banking ought to create more policy space to balance out various objectives while utilizing a broader array of instruments. In particular, employment creation and more rapid economic growth should join inflation and stabilization more generally as key goals of central bank policy. This paper outlines why a shift away from inflation targeting, the increasingly fashionable, but problematic approach to central bank policies, and a move toward a more balanced approach is both feasible and desirable.

The rest of the paper is organized as follows. In the next section, we briefly survey the macroeconomic record of IT and its current structure. Section 3 focuses on the role of the exchange rate as one of the key macro prices, and discusses alternative theories of its determination. We also make remarks on the issue of inflation targeting in the context of the so-called 'trilemma' of monetary policy. In Section 4 we discuss various alternatives to inflation focused central banks, concentrating on the results of a multi-country research project undertaken with the support of the United Nations Department of Economic and Social Affairs (UN-DESA), among other organizations. This section shows that there are viable, socially productive alternatives to inflation targeting, including those that focus on employment generation, and makes the case that these alternatives should be further developed. Section 5 concludes. 
Table 1. Inflation targeting countries: initial conditions and modalities.

\begin{tabular}{|c|c|c|c|c|}
\hline $\begin{array}{l}\text { Developing countries } \\
\text { (in order of adoption) }\end{array}$ & $\begin{array}{l}\text { IT adoption } \\
\text { rate }\end{array}$ & $\begin{array}{c}\text { Inflation } \\
\text { rate at start } \\
(\%, \text { per annum })\end{array}$ & $\begin{array}{c}\text { Current } \\
\text { inflation target } \\
(\%, \text { per annum })\end{array}$ & $\begin{array}{l}\text { Officially declared } \\
\text { policy instrument }\end{array}$ \\
\hline Israel & 1997Q2 & 8.5 & $1-3$ & Headline $\mathrm{O} / \mathrm{N}$ rate \\
\hline Czech Republic & 1998Q1 & 13.1 & $3( \pm 1)$ & 2-week repo \\
\hline Poland & 1998Q4 & 9.9 & $2.5( \pm 1)$ & 28-day intervention \\
\hline Brazil & 1999Q2 & 3.3 & $4.5( \pm 2)$ & Selic $\mathrm{O} / \mathrm{N}$ rate \\
\hline Chile & 1999Q3 & 2.9 & $2-4$ & $\mathrm{O} / \mathrm{N}$ rate \\
\hline Colombia & 1999Q3 & 9.3 & $5( \pm 0.5)$ & Repo \\
\hline South Africa & 2000Q1 & 2.3 & $3-6$ & \\
\hline Thailand & 2000Q2 & 1.7 & $0-3.5$ & 14-day repo \\
\hline Korea & 2001Q1 & 3.2 & $2.5-3.5$ & $\mathrm{O} / \mathrm{N}$ call rate \\
\hline Mexico & 2001Q1 & 8.1 & $3( \pm 1)$ & 91-day Cetes \\
\hline Hungary & 2001Q2 & 10.5 & $3.5( \pm 1)$ & 2-week deposit \\
\hline Peru & 2002Q1 & -0.8 & $2.5( \pm 1)$ & \\
\hline The Philippines & 2002Q1 & 3.8 & $5-6$ & Reverse repo \\
\hline Slovak Republic & 2005Q1 & 3.2 & $3.5( \pm 1)$ & \\
\hline Indonesia & 2005Q3 & 7.8 & $5.5( \pm 1)$ & 1-month SBI \\
\hline Romania & 2005Q3 & 8.8 & $7.5( \pm 1)$ & \\
\hline Turkey $^{\mathrm{a}}$ & 2006Q1 & 7.8 & $5( \pm 2)$ & $\mathrm{CB} \mathrm{O} / \mathrm{N}$ rate \\
\hline Turkey ${ }^{b}$ & 2001Q2 & 82.0 & n.a. & $\begin{array}{l}\mathrm{CB} \text { net domestic } \\
\text { assets }\end{array}$ \\
\hline \multicolumn{5}{|l|}{ Industrial countries } \\
\hline New Zealand & 1990Q1 & 7.0 & $1-3$ & Cash rate \\
\hline Canada & 1991Q1 & 6.2 & $1-3$ & $\mathrm{O} / \mathrm{N}$ funding rate \\
\hline United Kingdom & 1992Q4 & 3.6 & 2 & Repo \\
\hline Sweden & 1993Q1 & 4.8 & $2( \pm 1)$ & Repo \\
\hline Australia & 1993Q2 & 1.9 & $2-3$ & Cash rate \\
\hline Iceland & 2001Q1 & 3.9 & 2.5 & \\
\hline Norway & 2001Q1 & 3.7 & 2.5 & \\
\hline \multicolumn{5}{|l|}{ Candidate countries } \\
\hline Costa Rica, Egypt, Ukrains & $\begin{array}{l}\text { Near term } \\
(1-2 \text { years })\end{array}$ & & & \\
\hline $\begin{array}{l}\text { Albania, Armenia, Botswana, } \\
\text { Dominican Republic, } \\
\text { Gautemala, Mauritius, } \\
\text { Uganda, Angola, Azerbaijian, } \\
\text { Georgia, Moldova, Serbia, Sri } \\
\text { Lanka, Vietnam, Zambia }\end{array}$ & $\begin{array}{l}\text { Medium } \\
\text { term }(3-5 \\
\text { years })\end{array}$ & & & \\
\hline $\begin{array}{l}\text { Belarus, China, Kenya, Kyrgyz } \\
\text { Republic, Moldova, Serbia, Sri } \\
\text { Lanka, Vietnam, Zambia, } \\
\text { Bolivia, Honduras, Nigeria, } \\
\text { Papua New Guinea, Sudan, } \\
\text { Tunisia, Uruguay, Venezuela }\end{array}$ & $\begin{array}{l}\text { Long term } \\
(>5 \text { years })\end{array}$ & & & \\
\hline
\end{tabular}

Source: Batini et al. (2006).

Notes: a Official adoption date for Turkey. ${ }^{\mathrm{b}}$ Turkish CB declared 'disguised inflation targeting' in the aftermath of the 2001 February crisis. O/N, over-night interest rate; CB, Central Bank; SBI, 1-month Bank of Indonesia Certificates; n.a., not available. 


\section{Macroeconomic record of IT}

Much of the existing literature on the record of IT has focused on whether systemic risks and accompanying volatility has been reduced in the IT economies, and whether inflation has come down actually in response to adoption of the framework itself or as a result of a set of 'exogenously welcome' factors. To be sure, there is a fair amount of agreement that IT has been associated with reductions in inflation. Furthermore, exchange rate pass-through effects were reportedly reduced and consumer prices have become less prone to shocks (Edwards 2005; Mishkin and Schmidt-Hebbel 2001). Yet, existing evidence also suggests that IT has not yielded inflation below the levels attained by the industrial non-targeters that have adopted other monetary regimes (Ball and Sheridan 2003; Roger and Stone 2005). Moreover, even if domestic monetary policy has reduced inflation, the hoped for gains in employment have, generally, not materialized; and, for many countries following this orthodox approach, economic growth has not significantly increased.

On the 'qualitative' policy front, it is generally argued that with the onset of central bank independence, communication and transparency have improved and the $\mathrm{CBs}$ have become more 'accountable'. Yet, little is known about the true costs of IT on potential output growth, employment, and on incidence of poverty and income distribution. Bernanke et al. (1999) and Epstein (2008), for instance, report evidence that inflation targeting central banks do not reduce inflation at any lower cost than other countries' central banks in terms of forgone output. That is, inflation targeting does not appear to increase the credibility of central bank policy and therefore, does not appear to reduce the sacrifice ratio. Per contra, based on an econometric study of a large sample of inflation targeters and non-targeters, Corbo et al. (2001) concluded that sacrifice ratios have declined in the emerging market economies after adoption of IT. They also report that output volatility has fallen in both emerging and industrialized economies after adopting inflation targeting. This position is recently complemented by a study of the International Monetary Fund (IMF) economists, who, using a complex econometric model and policy simulations, report findings that inflation targeting economies experience reductions in the volatility in inflation, without experiencing increased volatility in real variables such as real gross domestic product (GDP) (Batini et al. 2006). According to these estimates, inflation targeting central banks do enhance economic 'stability' relative to other monetary rules, such as pegged exchange rates and monetary rules.

However, in the assessments of 'stability', these papers do not consider the issue of the stability of asset prices, including exchange rates, stock prices and other financial asset prices. As we discuss further below, asset price stability may need to be included in a full analysis of the impact of inflation targeting on overall economic stability.

Asset price stability aside, while intriguing, these results are only as strong as the simulation model on which they are based and are only as relevant as the relevance of the questions they pose. Moreover, they are only as broad as the alternatives they explore. On all these scores, these results are problematic. First, they do not simulate the impact of inflation targeting relative to other possible policy regimes, such as targeting the real exchange rate as discussed below. Second, the model is based on estimates of potential output that are themselves affected by monetary policy. Hence, if monetary policy slows economic growth, it also lowers the rate of growth of potential output and, therefore reduces the gap between the two, thereby appearing to stabilize the economy.

A further point pertains to the practical issue of setting the targeted rate of inflation itself. Even if the advocated requisites of the IT regime are taken for granted, it is not yet clear what the practically targeted rate of inflation should be. Even though there appears to be a consensus among the advocates of the IT regime that the inflation target has to be 'as low as possible', there is no theoretical guideline on the precise optimal numerical magnitude of the target itself; and as 
such, it smacks of more of an ideological claim than a careful calculation. Most disturbing is the common belief that what is good for the industrialized/developed market economies should simply be replicated by the developing countries as well. That this may not be the case is forcefully argued in Pollin and Zhu (2006). Based on their non-linear regression estimates of the relationship between inflation and economic growth for 80 countries over the period 1961-2000, Pollin and Zhu report that higher inflation is associated with moderate gains in GDP growth up to a roughly $15-18 \%$ inflation threshold. Furthermore they report that there is no justification for inflation-targeting policies as they are currently being practiced throughout the middle- and lowincome countries, that is, to maintain inflation with a $2-6 \%$ band.

Moreover, we have other evidence on the negative consequences of monetary policy designed to produce extremely low levels of inflation in developing countries. Braunstein and Heintz show that contractionary monetary policy used to fight inflation often has a differentially negative impact on the employment rates of women relative to men (Braunstein and Heintz 2008).

Given the possible negative costs of inflation targeting on output and employment, there should be some direct survey evidence indicating people's preferences with respect to inflation and unemployment. While some studies have indicated that people have an absolute preference for low inflation, Arjun Jayadev (2008) reports on survey results asking people in different countries and income levels what is their bigger concern, high inflation or high unemployment. His main result is that, in his sample, poorer people are more concerned about high unemployment than high inflation, while richer respondents have the opposite preferences. Hence, concerns over employment and inflation probably have an important class dimension to them, something that economists and historians have suspected for many years, but which policy makers often claim to be irrelevant.

An overall picture of the selected macroeconomic indicators of the inflation targeters can be obtained from Tables 2 and 3. In Table 2, we provide information on the observed behavior of selected macro aggregates as annual averages of 5 years before the adoption of the IT vs the annual average after the adoption date to the current period. Table 3 keeps the same calendar frames and reports data on key macro prices, viz. the exchange rate and interest rates.

As highlighted in the text, evidence on the growth performance of the IT countries is mixed. Taking the numbers of Table 2 at face value, we see that seven of the 21 countries report a decline in the average annual rate of real growth, while three countries (Canada, Hungary and Thailand) have not experienced much of a shift in their rates of growth. Yet, clearly it is quite hard to disentangle the effects of the IT regime from other direct and indirect effects on growth. One such factor is the recent financial glut in the global asset markets and the associated surge of the household deficit spending bubble. The Institute of International Finance data reveal, for instance, that the net capital inflows to the developing economies as a whole have increased from US\$47 billion in 1998, to almost US\$400 billion in 2006, surpassing their peak before the Asian crisis of 1997. As the excessive capital accumulation in telecommunications and the dot.com high tech industries phased out in the late 1990s, the global financial markets seem to have entered another phase of expansion, and external effects such as these make it hard to isolate the growth impacts of the IT regimes.

Despite the inconclusive verdict on the growth front, the figures on unemployment indicate a significant increase in the post-IT era. Only three countries of our list (Chile, Mexico and Switzerland) report a modest decline in their rates of unemployment in comparison to the pre-IT averages. The deterioration of employment performance is especially pronounced (and puzzling) in countries such as The Philippines, Peru and Turkey where rapid growth rates were attained. The increased severity of unemployment at the global scale seems to have affected the IT-countries equally strongly, and the theoretical expectation that 'price stability would bring growth and employment in the long run' seems quite far from having materialized as of yet. 
Table 2. Selected macroeconomic aggregates in the IT countries.

\begin{tabular}{|c|c|c|c|c|c|c|c|c|c|}
\hline \multirow[b]{2}{*}{ Country } & \multirow{2}{*}{$\begin{array}{l}\text { Year IT } \\
\text { started }\end{array}$} & \multicolumn{2}{|c|}{ Growth rate } & \multicolumn{2}{|c|}{$\begin{array}{l}\text { Unemployment } \\
\text { rate }\end{array}$} & \multicolumn{2}{|c|}{$\begin{array}{c}\text { Trade balance } \\
\text { (external balance } \\
\text { on goods and } \\
\text { services)/GDP (\%) }\end{array}$} & \multicolumn{2}{|c|}{$\begin{array}{l}\text { CB foreign reserves } \\
\text { (US } \$ \text { millions) }\end{array}$} \\
\hline & & Before & After & Before & After & Before & After & Before & After \\
\hline New Zealand & 1990 & 2.7 & 3.0 & 4.2 & 6.9 & 0.4 & 1.3 & 2897.9 & 4623.2 \\
\hline Canada & 1991 & 2.9 & 2.8 & 8.4 & 8.7 & 0.5 & 2.7 & $11,964.0$ & $24,256.0$ \\
\hline UK & 1992 & 2.2 & 2.7 & 7.4 & 5.2 & -2.5 & -1.6 & $39,666.5$ & $37,408.5$ \\
\hline Sweden & 1993 & 0.8 & 2.7 & 2.8 & 6.1 & 1.3 & 6.2 & $15,399.0$ & $18,521.8$ \\
\hline Australia & 1994 & 2.2 & 3.9 & 8.6 & 7.3 & -0.6 & -1.3 & $13,777.9$ & $20,337.1$ \\
\hline Israel & 1997 & 5.8 & 3.1 & 8.5 & 9.4 & -14.6 & -7.2 & 7567.3 & $24,421.1$ \\
\hline Czech Republic $^{\mathrm{a}}$ & 1998 & 4.5 & 3.2 & 4.0 & 8.9 & -3.4 & -1.8 & 9172.5 & $21,686.5$ \\
\hline Poland & 1998 & 7.9 & 3.7 & 14.3 & 16.7 & 0.0 & -4.1 & $12,591.8$ & $31,581.8$ \\
\hline Brazil $^{\text {b }}$ & 1999 & 3.2 & 2.3 & 7.0 & 9.8 & -1.7 & 1.0 & $47,701.3$ & $42,304.5$ \\
\hline Colombia & 1999 & 3.3 & 2.3 & 11.1 & 15.8 & -6.0 & -0.5 & 7567.3 & $24,421.1$ \\
\hline Mexico & 1999 & 1.7 & 4.8 & 2.7 & 1.9 & -0.5 & -1.9 & $20,630.9$ & $51,396.6$ \\
\hline South Africa ${ }^{\mathrm{c}}$ & 2000 & 2.6 & 3.8 & n.a. & 27.7 & 0.0 & 0.0 & $15,860.0$ & 9580.0 \\
\hline Switzerland & 2000 & 1.4 & 1.7 & 4.1 & 3.1 & 0.1 & 0.1 & $38,277.1$ & $40,646.5$ \\
\hline Thailand & 2000 & 1.5 & 1.7 & 1.9 & 2.4 & 0.0 & 0.1 & $32,556.1$ & $40,474.8$ \\
\hline Korea & 2001 & 4.6 & 4.5 & 4.4 & 3.7 & 0.0 & 0.0 & $55,299.5$ & $157,739.2$ \\
\hline Hungary & 2001 & 4.2 & 4.2 & 8.0 & 6.1 & -1.3 & -2.9 & 9918.1 & $13,652.1$ \\
\hline Peru $^{\mathrm{d}}$ & 2002 & 2.0 & 5.2 & 7.8 & 10.2 & -3.2 & -0.4 & 9264.8 & $11,222.9$ \\
\hline Philippines & 2002 & 3.1 & 5.1 & 10.2 & 11.5 & -3.6 & -0.7 & $11,282.6$ & $14,006.6$ \\
\hline Indonesia & 2005 & 4.6 & 5.6 & 6.5 & 10.3 & 7.3 & -4.6 & $31,326.7$ & $32,989.2$ \\
\hline Turkeye & 2006 & 4.5 & 7.8 & 9.9 & 10.4 & -9.8 & -11.0 & $33,237.4$ & $56,990 / 4$ \\
\hline Turkey $^{f}$ & 2001Q2 & 4.0 & 4.5 & 6.6 & 10.0 & -7.5 & -9.8 & $20,083.4$ & 33237.4 \\
\hline
\end{tabular}

Source: IMF Statistics and Asian Development Bank.

Notes: ${ }^{a}$ The period before the inflation targeting refers to the period of 1994-1997 for 'growth' and 'CPI inflation' for the Czech Republic. ${ }^{\mathrm{b}}$ The period before the inflation targeting refers to the period of 1996-1998 for reserves in Brazil. ${ }^{\mathrm{c}}$ The period before the inflation targeting refers to the period of 1994-1997 and after inflation targeting refers to the period 1999-2004 for unemployment rate in South Africa. Note that due to change in methodology and data coverage, unemployment figures are not directly comparable before and after apartheid. ${ }^{\mathrm{d}}$ The period before the inflation targeting refers to the period of 2003-2004 for unemployment rate in Peru. Official adoption date for Turkey is 2006. However, Turkish CB declared "disguised inflation targeting' in the aftermath of the 2001 February crisis.

Before, Annual average of 5 years prior to adoption; After, annual averages from the time of adoption of IT until the most recent period for which data are available.

The adjustment patterns on the balance of foreign trade have been equally diverse. Ten of the 21 countries in Table 2 achieved higher (improved) trade surpluses (balances). While there have been large deficit countries such as Turkey, Mexico, The Philippines, and Australia, there were also sizable surplus generators such as Brazil, Korea, Thailand, Canada, and Sweden. Not surprisingly much of the behavior of the trade balance could be explained by the behavior of the real exchange rates. This information is tabulated in Table 3 .

Table 3, as previously in Table 2 above, calculates the annual averages of the five-year period before the IT vs annual averages after IT to-date. Focusing on the inflation-adjusted real exchange rate movements, we find a general tendency towards appreciated currencies in the aftermath of adoption of the IT regimes. Mexico, Indonesia, Korea and Turkey are the most significant currency appreciating countries, while Brazil, and to some extent Colombia, have pursued active export promotion strategies and maintained real depreciation. The Czech Republic, Switzerland 
Table 3. Macroeconomic prices in the IT countries.

\begin{tabular}{|c|c|c|c|c|c|c|c|c|c|}
\hline \multirow[b]{2}{*}{ Country } & \multirow{2}{*}{$\begin{array}{l}\text { Year IT } \\
\text { started }\end{array}$} & \multicolumn{2}{|c|}{$\begin{array}{l}\text { Inflation rate } \\
\text { (variations in } \\
\text { CPI) }\end{array}$} & \multicolumn{2}{|c|}{$\begin{array}{c}\text { Exchange } \\
\text { rate real } \\
\text { depreciation }^{1,2}\end{array}$} & \multicolumn{2}{|c|}{$\begin{array}{c}\mathrm{CB} \text { real } \\
\text { interest rate }\end{array}$} & \multicolumn{2}{|c|}{$\begin{array}{l}\text { Public assets } \\
\text { real interest } \\
\text { rate }^{3,4}\end{array}$} \\
\hline & & Before & After & Before & After & Before & After & Before & After \\
\hline New Zealand & 1990 & 11.6 & 2.2 & -7.8 & -0.6 & 7.0 & 5.5 & 2.1 & 5.1 \\
\hline Chile $^{\mathrm{a}}$ & 1991 & 19.7 & 7.2 & -6.0 & -4.0 & $\ldots$ & 0.0 & -16.0 & -4.6 \\
\hline Canada & 1991 & 4.5 & 2.1 & -7.5 & -1.7 & 6.0 & 2.6 & 5.8 & 2.5 \\
\hline UK & 1992 & 6.4 & 2.6 & -2.4 & -2.2 & 5.4 & 3.0 & 5.0 & 2.8 \\
\hline Sweden & 1993 & 6.9 & 1.5 & -8.5 & 1.2 & 2.8 & 1.7 & 5.0 & 2.9 \\
\hline Australiab $^{\mathrm{b}}$ & 1994 & 4.2 & 2.5 & -6.9 & -1.1 & 7.1 & 3.2 & 6.3 & 4.0 \\
\hline Israel & 1997 & 11.3 & 3.1 & -4.2 & 0.9 & 2.0 & 5.0 & 1.5 & 5.0 \\
\hline Czech Republic ${ }^{\mathrm{c}}$ & 1998 & 9.1 & 3.1 & -6.6 & -6.2 & 1.9 & 0.7 & 0.0 & 0.9 \\
\hline Poland $^{\mathrm{d}}$ & 1998 & 24.1 & 4.7 & -4.5 & -4.6 & 1.6 & 6.2 & 1.8 & 11.6 \\
\hline Brazil & 1999 & 819.2 & 7.9 & -428.0 & 5.5 & -782.6 & 15.7 & -786.9 & 12.4 \\
\hline Colombia & 1999 & 20.4 & 7.5 & -9.5 & 0.5 & 18.4 & 6.6 & 1.5 & 2.0 \\
\hline Mexico & 1999 & 24.5 & $7 / 2$ & 2.8 & -4.6 & 7.5 & 5.0 & 3.2 & 3.8 \\
\hline Thailand & 2000 & 5.1 & 2.2 & 4.5 & -1.0 & 4.9 & 1.6 & 4.7 & 3.1 \\
\hline South Africa ${ }^{\mathrm{e}}$ & 2000 & 7.3 & 5.1 & 4.3 & -2.5 & 8.6 & 4.4 & 7.3 & 4.2 \\
\hline Switzerland & 2000 & 0.8 & 1.0 & 1.6 & -3.7 & 0.2 & 0.1 & 0.9 & 0.3 \\
\hline Korea & 2001 & 4.0 & 3.3 & 6.0 & -5.0 & -0.2 & -1.0 & 6.5 & 2.1 \\
\hline Hungary & 2001 & 15.2 & 5.9 & 2.5 & -12.4 & 2.0 & 3.4 & 2.3 & 3.4 \\
\hline Peru ${ }^{\mathrm{d}}$ & 2002 & 5.0 & 1.9 & -1.6 & 1.4 & 9.3 & 2.0 & 3.8 & -0.5 \\
\hline Philippines & 2002 & 6.3 & 5.0 & 8.7 & -3.0 & 5.1 & 0.9 & 5.2 & 1.2 \\
\hline Indonesia & 2005 & 8.0 & 10.5 & -6.2 & -1.9 & 4.2 & 2.3 & 4.1 & -2.4 \\
\hline Turkeyf & 2006 & 28.3 & 10.5 & -6.3 & -8.2 & 11.7 & 7.5 & 14.8 & 10.5 \\
\hline Turkey $^{\mathrm{f}}$ & 2001Q2 & 74.1 & 28.3 & -3.9 & -6.3 & -13.3 & 12.7 & 23.9 & 15.5 \\
\hline
\end{tabular}

Source: IMF statistics.

Notes: ${ }^{1} \mathrm{~A}$ rise in value indicates depreciation. Annual average market rate is used for: UK Canada, turkey, Australia, New Zealand, Brazil, Peru, Indonesia, Korea, and the Philippines. Annual average official rate is used for: Colombia, Thailand, Hungary, Poland, and Switzerland. Principle rate is used for: South Africa, Mexico, and the Czech Republic.

${ }^{2}$ Nominal values are deflated by the corresponding inflation averages (CPI column). ${ }^{3}$ Sweden, New Zealand, Canada, bank rate; Mexico, banker's acceptance. ${ }^{4}$ Colombia, Interbankaria TBS; Peru and Chile, savings rate; New Zealand, newly issued 3 months Treasury bill rates; Indonesia, 3 months deposit rate; Korea, National Housing bond rate; Thailand, Government bond yield rate.

${ }^{\mathrm{a}}$ The period after the inflation targeting refers to the period of 1993-2005; the period before the inflation targeting refers to the period of 1987-1990. ${ }^{\mathrm{b}}$ Treasury Bill, the period after the inflation targeting refers to the period of 1994-2000; CB rate, the period after the inflation targeting refers to the period of $1994-1995$. $^{\mathrm{c}}$ The period before the inflation targeting refers to the period of 1994-1997. ${ }^{\mathrm{d}}$ Treasury Bill rates, the period after the inflation targeting refers to the period of 1998-2000. ${ }^{\mathrm{e}}$ Treasury Bill, the period before the inflation targeting refers to the period of 1994-2000. ${ }^{\mathrm{f}}$ Official adoption date for Turkey is 2006. However, CB declared 'disguised inflation targeting' in the aftermath of the 2001 February crisis.

and Hungary are observed to have experienced currency appreciation, and Poland seems to have maintained an appreciating path for its real exchange rate.

Clearly much of this generalized trend towards appreciation can be explained by the increased expansion of foreign capital inflows owing to the global financial glut mentioned above. With the IT central bankers announcing a 'no-action' stance against exchange rate movements led by the 'markets', a period of expansion in the global asset markets has generated strong 
tendencies for currency appreciation. What is puzzling, however, is the rapid and very significant expansion in the foreign exchange reserves reported by the IT central banks. As reported in the last two columns of Table 2 above, foreign exchange reserves held at the CBs rose significantly in the aftermath of the IT regimes. The rise of reserves was especially pronounced in Korea, The Philippines and Israel where almost a five-fold increase had been witnessed. Of all the countries surveyed in Table 3, UK and Brazil are the only two countries that had experienced a fall in their aggregate reserves. ${ }^{1}$

This phenomenon is puzzling because the well-celebrated 'flexibility' of the exchange rate regimes were advocated precisely with the argument that, under the IT framework, the CBs would gain freedom in their monetary policies and would no longer need to hold reserves to defend a targeted rate of exchange. In the absence of any officially stated exchange rate target, the need for holding such sums of foreign reserves at the CBs should have been minimal. The proponents of the IT regimes argue that the CBs need to hold reserves to 'maintain price stability against possible shocks'. Yet, the acclaimed 'defense of price stability' at the expense of such large and costly funds that are virtually kept idle at the IT central banks' reserves is questionable in an era of prolonged unemployment and slow investment growth, and needs to be justified more fully.

We now turn to the issue of exchange rate policy in an IT framework more formally.

\section{The role of the exchange rate under IT}

As stated above, among the oft-stated requirements of the IT system is the implementation of a 'floating/flexible' exchange rate system in the context of free mobility of capital. In this context, central bank 'policy' has typically been reduced to merely 'setting the policy interest rate'. The role of the exchange rate as an adjustment variable has clearly increased over the last decade since the adoption of the floating exchange rate systems. In the meantime, however, the role of the interest rates and reserve movements has declined substantially as counter-cyclical instruments available to be used against shocks ${ }^{2}$ (see Table 2 above).

Against this background a number of practical and conceptual questions are inevitable: what is the role of the exchange rate in the overall macroeconomic policy when an explicit inflation targeting regime is adopted? Under what conditions should the central bank, or any other authority, react to shocks in the foreign exchange market? Also, perhaps more importantly, if an intervention in the foreign exchange market is regarded necessary against, say, the disruptive effects of an external shock, for example, speculative capital inflows, what are the proper instruments?

To the proponents of IT, the answer to these questions is simple and straightforward: the CB should not have any objective in mind with regards to the level of the exchange rate, yet it might interfere against the volatility of the exchange rate in so far as it affects the stability of prices. However, nuances remain. For what may be grouped under 'strict IT conformists', the CB should be concerned with the exchange rate only it affects its ability to forecast and target price inflation. Any other response to the foreign exchange market represents a departure from the IT system. Advocated in the seminal works by Bernanke et al. (1999) and Fischer (2001), the approach argues that attending to inflation targeting and reacting to the exchange rate are mutually exclusive. Beyond this assertion, the conformist view also holds that intervention in the foreign exchange market could confuse the public regarding the ultimate objective of the central bank with respect to its priorities, distorting expectations. In a world of a financial credibility game, such signals would be detrimental to the CB's authority.

Yet, while maintaining the IT objective, one can also distill a more active role for the exchange rate in the literature. As outlined in Debelle (2001) and Ho and McCauley (2003), this 'flexible IT' view proposes that the exchange rate can also be a legitimate policy objective alongside the inflation target. More formally, an operational framework for the 'flexible IT' view was 
envisaged within an expanded Taylor rule. Taylor (2000) argued, for instance, that an exchange rate policy rule can legitimately be embedded in a monetary rule that is consistent with the broad objectives of targeted inflation rate and the output gap.

In contrast to all this, the structuralist tradition asserts that irrespective of the conditionalities of foreign capital and boundaries of IT, it is very important for the developing economies to maintain a stable and competitive real exchange rate (SCRER) (see, e.g. Frenkel 2006; Frenkel and Taylor 2006; Frenkel and Ros 2006; Frenkel and Rapetti 2008). They argue that the real exchange rate can affect employment, and the economy more generally, through a number of channels: (1) by affecting the level of aggregate demand (the macroeconomic channel); (2) by affecting the cost of labor relative to other goods and thereby affecting the amount of labor hired per unit of output (the labor intensity channel); and (3) by affecting employment through its impact on investment and economic growth (the development channel). While the size and even direction of these channel effects might differ from country to country, maintaining a competitive and stable real exchange rate is likely to have a positive employment impact though some combination of these effects.

The general analytics of the SCRER within the context of an IT central bank is investigated in Cordero (2008). The gist of the structuralist case for SCRER, however, rests on a recent (and unfortunately not well understood and appreciated) paper by Taylor (2004). Resting his arguments on the system of social accounting identities, Taylor argues that the exchange rate can not be regarded as a simple 'price' determined by temporary macro equilibrium conditions. The mainstream case for exchange rate determination rests on the well-celebrated Mundell (1963) and Fleming (1962) model where the model rests on an assumed duality between reserves (fixed exchange rate system) vs flexible exchange rate adjustments. The orthodox mainstream model, according to Taylor, presupposes that a balance of payments exists with a potential disequilibrium that has to be cleared. This, however, is a false presumption. The exchange rate is not an 'independent' price and has no fundamentals such as a given real rate of return (or a trade deficit) that can make it self-stabilizing. In Taylor's (2004: 212) words, ‘ $\ldots$ the balance of payments is at most an accumulation rule for net foreign assets and has no independent status as an equilibrium condition. The Mundell-Fleming duality is irrelevant, and in temporary equilibrium, the exchange rate does not depend on how a country operates its monetary (especially international reserve) policy'.

Within the mainstream orthodoxy, the major policy implication of the Mundell-Fleming duality is the so-called 'trilemma', which commands that central banks can only have two out of three of the following: open capital markets, a fixed exchange rate system, and an autonomous monetary policy geared toward domestic goals. While this so-called 'trilemma' is not strictly true as a theoretical matter, in practice it does raise serious issues of monetary management. From our perspective, the real crux of the problem turns out to be the very narrow interpretation of the constraints of the trilemma: CBs are often thought to be restricted to choose two 'points' out of three. Yet, the constraints of the trilemma could as well be regarded as the boundaries of a continuous set of policies, as would emerge out of a bounded, yet continuous depiction of a 'policy triangle'. Thus, even within the boundaries of the trilemma a menu of choices does exist, ranging from administered exchange rate regimes to capital management/control techniques. In fact, many successful developing countries have used a variety of capital management techniques to manage these flows in order, among other things, to help them escape the rigid constraints of the so-called 'trilemma' (Ocampo 2002; Epstein, Grabel and Jomo 2005).

\section{Socially responsible alternatives to inflation targeting central bank policies}

Given the theoretical, empirical and policy problems associated with strict inflation targeting there is a major need for clear and concrete monetary policy alternatives that can achieve more 
socially desirable outcomes. Developing such alternatives has been the motivation for the multicountry research project whose main results are described in this special issue. In this section we briefly summarize some of the key findings of this series of country studies undertaken by a team of researchers working on a Political Economy Research Institute (PERI) (University of Massachusetts, Amherst)/Bilkent project on alternatives to inflation targeting. More detail can be found in the papers that follow.

A range of alternatives to inflation targeting were developed by these researchers, from modest changes in the targeting framework to allow for more focus on exchange rates and a change in the index of inflation used, to a much broader change in the overall mandate of the central bank to a focus on employment targeting, rather than inflation targeting.

It has to be noted at the outset that 'inflation control' is identified as among the crucial ultimate objectives in all country studies summarized below. Thus, there is a clear consensus among the authors that controlling inflation is important and desirable. At the same time, all agree that the current prescription insisting on 'very low' rates of inflation at the $2-4 \%$ band is not warranted, and that responsibilities of the central banks, particularly in developing countries, must be broader than that. Accordingly, the policy matrix of the CBs should include other crucial 'real' variables that have a direct impact on employment, poverty, and economic growth, such as the real exchange rate and/or investment allocation. They also agree that in many cases, central banks must broaden their available policy tools to allow them to reach multiple goals, including, if necessary, the implementation of capital management techniques.

\subsection{Modest but socially responsible adjustments to the inflation targeting regime}

Some of the country studies in the PERI/Bilkent project proposed only modest changes to the inflation targeting regime. In the case of Mexico, for example, the authors argue that the inflation targeting regime has allowed for more flexible monetary policy than had occurred under regimes with strict monetary targets or strict exchange rate targets (Galindo and Ros 2008). They suggest modifying the IT framework to make it somewhat more employment friendly. In the case of Mexico, Galindo and Ros find that monetary policy was asymmetric with respect to exchange rate movements - tightening when exchange rates depreciated, but not loosening when exchange rates appreciated. This lent a bias in favor of an over-valued exchange rate in Mexico. So they propose a 'neutral' monetary policy so that the central bank of Mexico responds symmetrically to exchange rate movements and thereby avoids the bias toward over-valuation without fundamentally changing the inflation targeting framework. In their own words, 'the central bank would promote a competitive exchange rate by establishing a sliding floor to the exchange rate in order to prevent excessive appreciation (an "asymmetric band ..."). This would imply intervening in the foreign exchange market at times when the exchange rate hits the floor (i.e. an appreciated exchange rate) but allows the exchange rate to float freely otherwise.' They point out that such a floor would work against excessive capital inflows by speculators because they would know the central bank will intervene to stop excessive appreciation. If need be, Galindo and Ros also propose temporary capital controls, as do some of the other authors from the PERI/Bilkent project.

In his study of Brazil, Nelson Barbosa-Filho (2008) also proposed extending the inflation targeting framework, but in a more dramatic way. According to Barbosa-Filho because of Brazil's past experience with high inflation, the best policy is to continue to target inflation while the economy moves to a more stable macroeconomic situation. However, the crucial question is not to eliminate inflation targeting, but actually make it compatible with fast income growth and a stable public and foreign finance (Barbosa-Filho 2008).

Given Brazil's large public debt, Barbosa-Filho proposes that the targeted reduction in the real interest rate would reduce the Brazilian debt service burdens and help increase productive 
investment. In terms of the familiar targets and instruments framework, he proposes that the Brazilian central bank choose exports, inflation and investment as ultimate targets, and focus on the inflation rate, a competitive and stable real exchange rate and the real interest rate as intermediate targets. Furthermore, in order to achieve these goals, the central bank can use direct manipulation of the policy interest rate, bank reserve requirements and bank capital requirements.

Brazil is not the only highly indebted country in our project sample. Turkey is another case with that problem. Here, too, the authors raise concerns about the conformist straightjacket of inflation targeting, and develop an alternative macroeconomic framework. Using a financiallinked computable general equilibrium model (CGE) for the case of Turkey, Telli, Voyvoda and Yeldan (2008) illustrate the real and financial sectoral adjustments of the Turkish economy under the conditionalities of twin targets: on the primary surplus to GNP ratio and on the inflation rate. They utilize their model to study the impact of a shift in policy from a strict inflation targeting regime, to one that calls for revisions of the primary fiscal surplus targets in favor of a more relaxed fiscal stance on public investments on social capital, together with a direct focus on the competitiveness of the real exchange rate. They further study the macroeconomics of a labor tax reform implemented through reduction of the payroll tax burden on the producers, and an active monetary policy stance via reduction of the central bank's interest rates. They report significant employment gains due to a policy of lower employment taxes. They also find that the economy's response to the reduction of the CB's interest rate is positive in general yet, very much dependent on the path of the real exchange rate; thus they also call for maintaining a stable real exchange rate path à la Frenkel, Rapetti, Ros and Taylor.

Frenkel and Rapetti (2008), in the case of Argentina, show that targeting a stable and competitive real exchange rate has been very successful in helping to maintain more rapid economic growth and employment generation. In the case of India, Jha (2008) also argues against an inflation targeting regime, and in favor of one that 'errs on the side of undervaluation of the exchange rate' with possible help from temporary resort to capital controls. Jha argues, that, to some extent, such a policy would be a simple continuation of policies undertaken in India in the past.

\subsection{More comprehensive alternatives to inflation targeting}

Other country case studies propose more comprehensive policy alternatives to simple inflationfocused monetary policy, including inflation targeting. Joseph Lim (2008) proposes a comprehensive alternative to inflation targeting for the case of the Philippines. He argues that the Philippine government has been seeking to achieve a record of dramatically higher economic growth, but that its monetary policy has been inadequate to achieve that goal. He therefore proposes an 'alternative' that 'clearly dictates much more than just a move from monetary targeting to inflation targeting' with the following proposals: (1) Maintenance of a competitive real exchange rate, either by pegging the exchange rate or intensively managing it as in South Korea. (2) Implementation of capital management techniques, as in China and Malaysia, to help manage the exchange rates. This should include strong financial supervision to prevent excessive undertaking of short-term foreign debt, and tax based capital controls on short term capital flows, as was used, for example in Chile. (3) An explicit statement of output and employment goals, as the central bank transits from a purely inflation-targeting regime. (4) Incomes and anti-monopoly policies to limit inflation to moderate levels and (5) Targeted credit programs, especially for export oriented and small and medium sized enterprises that can contribute to productivity growth and employment.

These policy proposals in broad outlines are similar to those proposed by Epstein (2008) for the case of South Africa, which, in turn, have been developed in a much broader framework and 
in more detail by Pollin et al. (2006). Pollin et al. developed an 'employment-targeted economic program' designed to accomplish this goal, with a focus on monetary policy, credit policy, capital management techniques, fiscal policy and industrial policy. The purpose of the program is to reduce unemployment rate by half in line with the government's pledge to reduce the official unemployment rate to $13 \%$ by $2014 .^{3}$ Here, 'employment targeting' replaces inflation targeting as the proposed operating principle behind central bank policy, and moderate inflation becomes an additional formal constraint which the central bank must take into account when formulating its policies.

\section{Concluding comments}

In this overview paper we have argued that the current day orthodoxy of central banking - namely, that the top priority goal for central banks is to keep inflation in the low single digits - is, in general, neither optimal nor desirable. This orthodoxy is based on several false premises: first, that inflation, in any magnitude, has high costs; second, that in a low inflation environment, economies will naturally perform best, and in particular, will generate high levels of economic growth and employment generation; and third, that there are no viable alternatives to this 'inflation-focused' monetary policy.

In fact, moderate rates of inflation have very low or no costs; and countries where central banks have predicted IT have not generally performed better in terms of economic growth or employment generation and in many cases have performed worse. Moreover, there are viable alternatives to inflation targeting, historically, presently, and looking forward.

Historically, countries both in the currently developed and developing worlds had central banks with multiple goals and tools, and pursued broad developmental as well as stabilization goals. Currently, very successful economies such as Argentina, China and India have central banks that are using a broad array of tools to manage their economies for developmental purposes. Looking forward, the PERI/Bilkent project on alternatives to inflation targeting and PERI's work on South Africa, have developed an array of 'real targeting' approaches to central banking which we believe are viable alternatives to inflation targeting and, in particular, do a better job than mere inflation targeting in balancing the developmental and stabilization functions of central banks.

\section{Acknowledgements}

We are indebted to Hasan Comert, Luis Rosero and Lynda Pickbourn for their diligent research assistance, and to Roberto Frenkel, Jose Antonio Ocampo, Jomo, K.S., Geoffrey Woglom, Refet Gürkaynak, James Heintz, Leonce Ndikumana, Arjun Jayadev and Robert Pollin for their valuable comments and suggestions on previous versions of the paper. Research for this paper was completed when Yeldan was a visiting Fulbright scholar at the University of Massachusetts, Amherst for which he acknowledges the generous support of the J. William Fulbright Foreign Scholarship Board and the hospitality of the Political Economy Research Institute at UMass, Amherst. We are also grateful to the funders of the PERI/Bilkent Alternatives to Inflation Targeting project, including UN-DESA, Ford Foundation, Rockefeller Brothers Fund and PERI. Needless to mention, the views expressed in the paper are solely those of the authors and do not implicate in any way the institutions mentioned above.

\section{Notes}

1. Brazil's case is actually explained in part by the recent decision (late 2005) of the Lula government to close its debt arrears with the IMF with early payments out of its reserves. 
2. Though, note the one sided increases in the aggregate reserves of the CBs. The social desirability and economic optimality of this phenomenon in the aftermath of the adoption of floating exchange rate systems is another issue that warrants further research.

3. As of March 2005, South Africa had an unemployment rate of anywhere from 26 to $40 \%$, depending on exactly how it is counted.

\section{References}

Adelman, I., and E. Yeldan. 2000. The minimal conditions for a financial crisis: a multi-regional intertemporal CGE model of the Asian crisis. World Development 28: 1087-1100.

Akyuz, Y. 2006. From liberalization to investment and jobs: lost in translation. Paper presented at the Carnegie Endowment for International Peace Conference, 14-15 April 2005, Washington DC.

Ball, L., and N. Sheridan. 2003. Does inflation targeting matter? IMF Working Paper No. 03/129.

Barbosa-Filho, N. H. 2008. Inflation targeting in Brazil. International Review of Applied Economics 22: 187-200.

Batini, N., P. Breuer, K. Kochhar, and S. Roger. 2006. Inflation targeting and the IMF. IMF Staff Paper, Washington DC, March.

Bernanke, B., T. Laubach, A. Posen, and F. Mishkin. 1999. Inflation targeting: lessons from the international experience. Princeton, NJ: Princeton University Press.

Braunstein, E., and J. Heintz. 2008. Gender bias and central bank policy: employment and inflation reduction. International Review of Applied Economics 22: 173-186.

Corbo, V.L.O., and K. Schmidt-Hebbel. 2007. Does inflation targeting make a difference? Central Bank of Chile Working Papers, No. 106.

Cordero, J. 2008. Economic growth under alternative monetary regimes: inflation targeting vs. real exchange rate targeting. International Review of Applied Economics 22: 145-160.

Debelle, G. 2001. The case for inflation targeting in East Asian countries. In Future Directions for Monetary Policies in East Asia, 65-87. Sydney: Reserve Bank of Australia.

Edwards, S. 2005. The relationship between exchange rates and inflation targeting revisited. NBER Working Paper No. W12163.

Epstein, G. ed. 2005. Financialization and the global economy. Northampton, Mass.: Edward Elgar.

Epstein, G. 2007. Central banks as agents of economic development. In Institutional Change and Economic Development, ed. Ha-Joon Chang. Helsinki: United Nations University Press. http://www. wider.unu.edu/publications/rps/rps2006/rp2006-54.pdf

Epstein, G. 2008. A employment targeting framework for central bank policy in South Africa. International Review of Applied Economics 22: 243-258.

Epstein, G., I. Grabel, and K.S. Jomo. 2005. Capital management techniques in developing countries: an assessment of experiences from the 1990's and lessons for the future. In Capital flight and capital controls in developing countries, ed. G. Epstein. Northampton, Mass.: Edward Elgar.

Fischer, S. 2001. Distinguished lecture on economics in government. Journal of Economic Perspectives 15, no. 2: 3-24.

Fleming, J.M. 1962. Domestic financial policies under fixed and floating exchange rates, staff papers, International Monetary Fund, Vol. 9, November, pp. 369-379.

Freeman, R. 2004. Doubling the global workforce: the challenges of integrating China, India, and the former Soviet block into the world economy. Paper presented at the conference on 'Doubling the Global Work Force', Institute of International Economics, 8 November, Washington DC.

Frenkel, R. 2004. Real exchange rate and employment in Argentina, Brazil, Chile and Mexico, paper prepared for the G-24, Washington, DC.

Frenkel, R., and M. Rapetti. 2008. Five years of competitive and stable real exchange rate in Argentina, 2002-2007. International Review of Applied Economics 22: 215-226.

Frenkel, R., and J. Ros. 2006. Unemployment and the real exchange rate in Latin America. World Development 34, no. 4: 631-646.

Frenkel, R., and L. Taylor. 2006. Real exchange rate, monetary policy, and employment: economic development in a garden of forking paths. Working Paper No. 19, Department of Economic and Social Affairs (DESA), United Nations, New York, February 2006.

Galindo, L.M., and J. Ros. 2008. Alternatives to inflation targeting in Mexico. International Review of Applied Economics 22: 201-214.

Heintz, J. (2006) Globalization, economic policy and employment: poverty and gender implications. Employment Strategy Department, Employment Strategy Papers 2006/3. Geneva: ILO. 
Ho, C., and R.N. McCauley. 2003. Living with flexible exchange rates: issues and recent experience in inflation targeting emerging market economies. BIS Working Papers, No. 130.

International Labor Office (ILO). 2004. Global Employment Trends 2004. Geneva: International Labor Office.

Jayadev, A. 2008. The class content of preferences towards anti-inflation and anti-unemployment policies. International Review of Applied Economics 22: 161-172.

Jha, R. 2008. Inflation targeting in India: issues and prospects. International Review of Applied Economics 22: $259-270$.

Lim, J. 2008. A review of Philippine monetary policy towards an alternative monetary policy. International Review of Applied Economics 22: 271-285.

Mishkin, F., and K. Schmidt-Hebbel. 2001. One decade of inflation targeting in the world: what do we know and what do we need to know? NBER Working Papers, No. 8397, July. www.nber.org/papers/ w8397

Mundell, R.A. 1963. Capital mobility and stabilization policy under fixed and flexible exchange rates. Canaidan Journal of Economics and Political Scienceno. 29: 475-485.

Ocampo, J.A. 2002. Capital-account and counter-cyclical prudential regulations in developing countries. WIDER, Discussion Paper, August.

Pollin, R., and A. Zhu. 2006. Inflation and economic growth: a cross-country nonlinear analysis. Journal of Post Keynesian Economics 28, no. 4: 593-614.

Pollin, R., G. Epstein, J. Heintz, and L. Ndikumana. 2006. An employment-targeted economic program for South Africa. Northampton, MA, Edward Elgar.

Roger, S., and M. Stone. 2005. On target? The international experience with achieving inflation targets. IMF Working Paper, WP/05/163, Washington DC.

Setterfield, M. 2006. Is inflation targeting compatible with post Keynesian economics? Journal of Post Keynesian Economics 28, no. 4: 653-671.

Setterfield, M. 2006. Is inflation targeting compatible with post Keynesian economics? Journal of Post Keynesian Economics 28, no. 4: 653-671.

Taylor, J.B. 2001. The role of the exchange rate in monetary policy rules. American Economic Review 91, no. 2: 263-267.

Taylor, L. 2004. Exchange rate indeterminacy in portfolio balance, Mundell-Fleming and uncovered interest parity models. Cambridge Journal of Economics 28, 205-227.

Telli, C., E. Voyvoda, and E. Yeldan. 2008. Macroeconomics of twin-targeting in Turkey: analytics of a financial CGE model. International Review of Applied Economics 22: 227-242. 